\title{
Ilja Erenburg i Dmitrij Fiłosofow: dwa spojrzenia na Polskę okresu międzywojennego*
}

\author{
Wiktoria MoczaŁowa
}

(Instytut Słowianoznawstwa RAN, Moskwa)

Dwóch Rosjan, emigrantów, ludzi należących do różnych generacji oraz kręgów kulturowych, o różnym pochodzeniu - Dmitrij Fiłosofow (I872-1940) i Ilja Erenburg (I89I-I967) znalazło się w Polsce w okresie międzywojennym: pierwszy w roku I9I9 uciekł z Rosji bolszewickiej i osiadł tu na stałe (zmarł w I940 roku), drugi zawitał zaledwie na dwa tygodnie (w grudniu $1927 \mathrm{roku})^{\mathrm{I}}$. Łatwo zrozumieć, że poglądy na Polskę, jej kulturę oraz stosunki polsko-rosyjskie tych dwóch osobowości różniły się zasadniczo, co dotyczy również poziomu wiedzy i bezpośredniego kontaktu z polską rzeczywistością. Fiłosofow, człowiek doskonale wykształcony (ukończył studia na wydziale prawa Uniwersytetu Petersburskiego, później został stażystą na Uniwersytecie w Heidelbergu), wykwintny arystokrata, esteta, publikujący w czasopiśmie „Świat sztuki” („Мир искусства”, I898-I904), jeden z organizatorów (wspólne z Dmitrijem Mereżkowskim, Wasylijem Rozanowem i Zinaidą Gippius) Stowarzyszenia Religijno-Filozoficznego (I90I-I903), miał całkowicie inne zaplecze kulturalne i doświadczenie ${ }^{2}$ niż młodszy od niego o dwadzieścia lat Erenburg, syn kupca i inżyniera (dyrektora browaru w Moskwie), samouk zwolniony z gimnazjum, rosyjski pisarz, poeta, dziennikarz, tłumacz z francuskiego i hiszpańskiego, który spędził

* Artykuł powstał w ramach kierowanego przez dr hab. Annę Sobieską projektu „Spojrzenie z ukosa...”. Kultura i literatura rosyjska oczami Polaków (na materiale czasopism polskich okresu międzywojennego). Grant NCN umowa nr UMO-2012/07/E/HS/03861.

1 „Do Polski przywiózł mnie impresario, dawałem odczyty o literaturze” (I. Erenburg, Ludi, gody, żyzn', podgot. I. I. Erenburg, B. Frezinski, Moskwa 1990, s. 506). Jeśli nie zaznaczono inaczej, wszystkie tłumaczenia pochodzą od autorki artykułu.

2 Zob. jego prace: А. Философов, Загадки русской культуры, сб. ст., сост., прим. Т. Ф. Прокопова, предисл. А. Н. Николюкина, Москва 2004; idem, Критические статьи и заметки (1899-1916), преА., сост. и прим. О. А. Коростелева, Москва 2010; idem, Pisma wybrane, t. 1: Trudna Rosja (19021916), oprac. P. Mitzner, Warszawa 2015; idem, Pisma wybrane, t. 2: Rosjanin w Polsce (1920-1936), wybór i oprac. P. Mitzner, kwerenda S. Kuziur, tłum. H. Dubyk, E. Skalińska, R. Szczęsny, Warszawa 2015. 
lata 1908-I9I7 oraz I92I-I940 na emigracji. (Przebywał głównie we Francji, gdzie przesiadywał w paryskiej kawiarni Rotonde, pisząc i słuchając wierszy w międzynarodowym towarzystwie, w którym bywali Picasso, Chagall, Modigliani, Apollinaire, ale także w Niemczech oraz Belgii, dużo bowiem podróżował po Europie³).

Sądząc po zestawieniu sporządzonym przez Jadwigę Urbańską, w latach I9ıI932 Erenburg był autorem najczęściej wzmiankowanym na łamach pism polskich spośród 24 pisarzy radzieckich 4 . Od roku 1924, kiedy w Polsce została wydana (uważana za najlepszą w jego twórczości) powieść Niezwykłe przygody Julia Jurenity i jego uczniów... (ze wstępem Juliusza Kadena-Bandrowskiego), był wielokrotnie publikowany, a na język polski przełożono prawie wszystko, co napisał5.

Wśród tłumaczy Erenburga w okresie międzywojennym znalazł się Aleksander $\mathrm{Wat}^{6}$, którego ocena pisarza rosyjskiego, jego postawy życiowej, zaangażowania politycznego i poszczególnych utworów jest ambiwalentna, ale też z czasem ewoluuje od całkowitego braku akceptacji do zrozumienia ${ }^{7}$.

Wydawnictwo Rój w 1927 roku zaprosiło popularnego pisarza, jedynego ówczesnego autora rosyjskiego, który doczekał się w Polsce wydania dzieł zebranych, do odwiedzenia Warszawy, Łodzi i Krakowa ${ }^{8}$. W wyniku tej podróży powstał składający się z szesnastu esejów krytyczny cykl $W$ Polsce (wchodzący w skład większego zbioru Wiza czasu-Bиза времени, poświęconego wrażeniom z podróży po Europie,

3 Zob.: В. Попов, Б. Я. Фрезинский, Илья Эренбург: Хроника жизни и творчества 1924-1931 (в документах, письмах, высказываниях и сообениях прессьь, свидетельствах современников), Санкт-Петербург, т. 2, 2000; J. Rubenstein, Tangled Loyalties. The Life and Times of Ilya Ehrenburg, Tuscaloosa 1996; E. Zarzycka-Bérard, Burzliwe życie Ilii Erenburga. Rosyjski los, żydowskie szczęście, tłum. A. Kozak, Warszawa 2002. Chociaż Erenburg żył jednym życiem z poetami i pisarzami, którzy emigrowali z Rosji, ale w przeciwieństwie do nich miał radziecki paszport - tak żartował na ten temat Wiktor Szkłowski: „Erenburg jest hojnie obdarzony przez naturę, ma paszport”. (B. Sarnow, Wstup, w: I. Erenburg, Ludi, gody, żyzn', s. 14). Aleksander Wat zaś nazywa Erenburga starym cynikiem, we wszystkich rynsztokach paryskich uturlanym (A. Wat, Mój wiek. Pamiętnik mówiony, rozm. prowadził, przedm. opatrzył Cz. Miłosz, Warszawa 1998, cz. 2, s. 150).

4 J. Urbańska, Radziecka powieść rosyjska w Polsce w latach 1918-1932, Wrocław 1966, s. 122-130. O Erenburgu można tam znaleźć 42 wzmianki, o Gorkim 10, o Pilniaku 9, o Sejfullinie 5, o Katajewie i Leonowie po 4, o Aleksym Tołstoju 3, o Wsiewołodzie Iwanowie 2. Zob. H. Wisner, Książka radziecka i rosyjska w drugiej Rzeczypospolitej, „Kwartalnik Historyczny” 1977, nr 4, s. 861.

5 Powieści Erenburga tłumaczone na język polski: Mitość Joanny Ney (1924), Rwacz (1925), Burzliwe życie Lejzorka Rojtszwańca (1928), Dzień wtóry (1934). Zob. B. Frezinski, Ilja Erenburg w Polsze (1923-1960), w: Russkije jewriei w Polsze, ried., sost. K. Kikoin, I. Obuchowa-Zielinska, M. Parchomowski, Jerusalem 2014, s. 81-292.

6 I. Erenburg, Trzynaście fajek, z upoważn. aut. tłum. A. Wat, Warszawa 1927; idem, Fabryka snów, z upoważn. aut. tłum. A. Wat, Warszawa 1933; idem, Dzień wtóry. Powieść, z upoważn. aut. tłum. A. Wat, Warszawa 1935.

7 Zob. P. Fast, Aleksander Wat o pisarzach rosyjskich: Boris Pasternaki Ilja Erenburg „Pamiętnik Literacki” 2010, z. 3, s. 153-163.

8 Zob. P. Van Poucke, Erenburg i Polsza, w: For East is East: liber amicorum Wojciech Skalmowski, „Orientalia Lovaniensia Analecta" 2003, nr 126, s. 151-160. 
który został wydany w Berlinie, w Moskwie ${ }^{9}$, ale później przez ponad 6o lat nie był publikowany w Rosji ${ }^{\text {Io }}$ ). Jarosław Iwaszkiewicz wspominał, że cykl $W$ Polsce był przedrukowany w „Twórczości” ", ale wyniki mojej kwerendy nie potwierdzają tego.

Wśród rosyjskich nowości na rynku księgarskim w Polsce w czasie, kiedy Erenburg zjawił się z wizytą, ,Wiadomości Literackie” wymieniały (wraz z informacją o publikacji tomów V-VII jego wydania zbiorowego) wiele pozycji: Koniec Rasputina Feliksa Jusupowa (1928) ${ }^{\mathrm{I} 2}$, Wospominanija (Pamiętniki, 1927) Siergieja Sazonowa ${ }^{\mathrm{I}}$, Tri stolicy (Podróż po Rosji sowieckiej, 1927) Wasilija Szulgina ${ }^{\mathrm{I}}$, Wospominanja terrorista Borisa Sawinkowa ${ }^{\mathrm{I} 5}$, powieści: Zagowor (Spisek, 1927) Marka Ałdanowa ${ }^{\mathrm{I} 6}$, Rosja na pieretomie (1927) Pawła Milukowa ${ }^{\mathrm{1}}$ S nami Bog (1927) Piotra Krasnowa ${ }^{\mathrm{18}}$ oraz

9 Berlin-Petropolis 1930; wyd. drugie poszerzone: Moskwa-Leningrad 1931; wyd. trzecie: Leningrad 1933.

10 Stało się to możliwe dopiero w niecenzurowanym zbiorze jego dzieł: I. Erenburg, W Polsze, w: idem, Sobranije soczinienij, w 8 t., t. 4, sost., podgot. tieksta I. I. Erenburg i B.J. Frezinskogo, kommient. B. Frezinskogo, W.W. Popowa, Moskwa 1991, s. 98-154. Podobny los spotkał krytyczny reportaż Antoniego Słonimskiego Moja podróż do Rosji, drukowany na łamach „Wiadomości Literackich” (1932, nr 27-35), a następnie w formie książkowej (wydawnictwo Rój). W Rosji sowieckiej wzbudził on protesty, w Polsce powojennej nie był wznawiany do r. 1997.

11 J. Iwaszkiewicz, Wspomnienie o Erenburgu, „Twórczość” 1967, nr 11, s. 94; B. Frezinski, Ilja Erenburg w Polsze (1923-1960), s. 284. Można przypuszczać, że Iwaszkiewicz miał na myśli publikację $Z$ pamiętników Erenburga, pisanych w latach sześćdziesiątych („Twórczość” 1964, nr 3, s. 42-46, tłum. W. Komarnicka). W tym miejscu dziękuję serdecznie dr Grażynie Pawlak za pomoc w poszukiwaniach informacji bibliograficznej.

12 Wspomnienia hrabiego Feliksa Jusupowa (1887-1967) o spisku mającym na celu zabicie ulubieńca rodziny carskiej Grigorija Rasputina (1869-1916) w grudniu 1916 r.

13 Siergiej Sazonow (1860-1927) - dyplomata rosyjski, w latach 1910-1916 minister do spraw zagranicznych Imperium Rosyjskiego. Kilka lat przebywał w Polsce, gdzie zwrócono mu posiadłość w Białostockiem na znak uznania jego propolskich sympatii.

14 Wasilij Szulgin (1878-1976) - rosyjski działacz polityczny, monarchista oraz nacjonalista; gdy był na emigracji, zimą 1925-1926 r., z fałszywymi dokumentami odwiedził Moskwę, Leningrad oraz Kijów, co opisał w książce.

15 Boris Sawinkow (1879-1925) - rosyjski rewolucjonista, terrorysta, uczestnik białego ruchu, pisarz (znalazł się pod wpływem Stanisława Przybyszewskiego). Uczęszczał do gimnazjum w Warszawie, przebywał na emigracji, został zaproszony do Polski przez Piłsudskiego w 1920 r., stworzył tu Rosyjski Komitet Polityczny, w skład którego wchodził m.in. Dmitrij Fiłosofow; wydawał wraz z Dmitrijem Mereżkowskim gazetę „Za swobodu!". Powstałe w latach 1905-1909 Wspomnienia terrorysty po pierwszej publikacji (1917-1918) były niejednokrotnie wznawiane.

16 Mark Ałdanow (1886-1957) - rosyjski pisarz, wielokrotnie nominowany do Nagrody Nobla, od r. 1919 na emigracji. Historyczna powieść Zagowor (Spisek, 1927) jest poświęcona zabójstwu Pawła I w 1801 r.

17 Paweł Milukow (1859-1943) - rosyjski działacz polityczny, historyk, publicysta, przywódca Partii Konstytucyjno-Demokratycznej, minister spraw zagranicznych w Rządzie Tymczasowym (1917), od 1919 r. na emigracji. Wspomniane dzieło wydane, w Paryżu w 1927 r., poświęcone jest okresowi bolszewickiemu rewolucji rosyjskiej. Majakowski wspomina o swej wizycie w Warszawie: „Moje przybycie zbiegło się z odmową wizy dla podróżującego z wykładami Milukowa. I w gazetach zaczęły pojawiać się groźne artykuły: «Zamiast Milukowa - Majakowski»; «Milukowowi nie wolno, Majakowskiemu - wolno»” (W. Majakowski, Powierch Warszawy, w: idem, Potnoje sobranije soczinienij, t. 8, Moskwa 1958, s. 349).

18 Wydana (w dwu tomach) w Berlinie powieść historyczna generała Piotra Krasnowa (1869-1947), rosyjskiego działacza wojskowego oraz politycznego, historyka, publicysty, pisarza, który uczestniczył w walce zbrojnej przeciwko bolszewikom. Od 1919 r. przebywał na emigracji. 
sztukę Dni Turbinów (1926) Michaiła Bułhakowa ${ }^{\text {I9 }}$. Jak widać, rosyjska literatura wydawana na emigracji lub w ZSRR była dobrze znana w Polsce międzywojennej ${ }^{20}$, nie miał zatem racji Erenburg, kiedy twierdził, że „ani języka rosyjskiego, ani gazet, ani książek. [...] Polska jest jakby zamknięta teraz dla kultury rosyjskiej”" ${ }^{\text {.I Nie }}$ dostrzegał (lub nie chciał dostrzec), że przeczą temu fakty: sam wygłaszał w Polsce wszystkie swoje przemówienia o literaturze radzieckiej po rosyjsku (a zbierało się na nich sporo słuchaczy), wydawane były gazety emigracyjne.

Mimo że Erenburg sam był (na wpół) emigrantem, w wywiadzie dla gazety „Epoka” ( 3 grudnia I927 r.) odpowiadał przecząco na pytanie o pisarzy rosyjskich tworzących poza ZSRR: „Nic nie powiem. Literatura rosyjska jest jedna, i znajduje się tam, gdzie naród rosyjski oraz mowa rosyjska”22 . Tego rodzaju wypowiedzi należy oceniać w kontekście kodeksu właściwego zachowania się pisarza radzieckiego za granicą. Po powrocie zaś wyznawał w liście prywatnym: „W Polsce było ciekawie, ale sztywno i męcząco. Musiałem przecież «trzymać sztandar»" ${ }^{23}$.

Erenburg nie zauważał - być może umyślnie - także działalności kulturalnej rosyjskich emigrantów w Polsce, chociaż był to znaczący fragment polskiej rzeczywistości międzywojennej, o czym dobitnie świadczą przeprowadzone w Polsce badania $^{24}$ oraz wymienione wyżej wydania prac Dmitrija Fiłosofowa. Zamiast tego pisał, że emigracja rosyjska w Polsce nie ma ani swego oblicza, ani własnych opinii, że jest służalcza w stosunku do kraju, który zapewnił jej schronienie ${ }^{25}$.

Zupełnie inaczej przedstawia warszawski okres życia i działalności Fiłosofowa badacz polski. Bazyli Białokozowicz stwierdza, że ten niezwykle płodny i twórczy pisarz był „opromieniony szczerą sympatią i przyjaźnią Marii i Józefa Czapskich”, pisze także:

\section{\Jako wydawca, redaktor i dziennikarz oraz wzięty publicysta i krytyk literacki znacznie wzbogacił tematycznie i problemowo rosyjskie cza- sopiśmiennictwo emigracyjne. W prasie rosyjskiej, ale też i polskiej,}

19 Michaił Buthakow (1891-1940) - pisarz i dramaturg rosyjski, w 1924 r. ukończył powieść Biata gwardia, opartą na własnych przeżyciach z okresu walk w Kijowie między wojskami bolszewików, Ukraińskiej Republiki oraz białych, później na jej podstawie napisał sztukę Dni Turbinów (1925).

20 Zob. też: A. Wat, Mój wiek. Pamiętnik mówiony, cz. 1, s. 86-90.

21 I. Erenburg, $W$ Polsze, s. 102.

22 Dokumienty i matieriaty po istorii sowietsko-polskich otnoszenij, t. 5. Nauka, Moskwa 1967, s. 237-238.

23 Cyt. za: B. Frezinski, Ilja Erenburg w Polsze (1923-1960), s. 88.

24 Zob. I. Obłąkowska-Galanciak, Gorzkie gody... Publicystyka i literacka dziatalność Dymitra Fitosofowa na emigracji, Olsztyn 2001; P. Mitzner, Warszawski „Domek w Kotomnie”. Rekonstrukcja, Warszawa 2014; idem, Warszawski krag Dymitra Fitosofowa, Warszawa 2015.

25 I. Erenburg, W Polsze, s. 130-131. 
publikował artykuły, szkice i eseje o sztuce i literaturze rosyjskiej oraz rosyjsko-polskich stosunkach literackich, wnosząc tym samym istotny wkład do rusycystyki polskiej okresu międzywojennego ${ }^{26}$.

Dodajmy, że wniósł też swój wkład do badań nad literaturą polską, pisząc artykuły o Adamie Mickiewiczu ${ }^{27}$, Cyprianie Kamilu Norwidzie ${ }^{28}$, Marii Dąbrowskiej $^{29}$, a także odegrał znaczącą rolę w polsko-rosyjskich stosunkach kulturalnych. Jak twierdzi Iwona Obłąkowska-Galanciak:

\section{1) Działalność Fiłosofowa w Warszawie należy zaliczyć do najlepszych przykładów, świadczących o godnych przejawach aktywności spo- łeczno-kulturalnej środowisk rosyjskich w Drugiej Rzeczypospolitej. Niezwykle interesującego i bogatego materiału badawczego dostar- cza w tym względzie zawartość pism emigracyjnych, wydawanych w Warszawie, tym bardziej iż gazety redagowane przez Fiłosofowa ${ }^{30}$ odróżniało od innych wydawnictw emigracyjnych właśnie otwarcie na kulturę międzywojennej Polski ${ }^{\mathrm{I}}$.}

Fiłosofow twierdził, że prawdziwa, „życiodajna” cywilizacja chroni swoich artystów, malarzy, rzeźbiarzy, poetów, muzyków i pozwala im na rozwój, podczas gdy cywilizacja bezkrwawa, a zarazem bezpłodna zachowuje świętoszków-mentorów i naśladowców drugiej klasy. W Polsce Fiłosofow zdołał zwrócić uwagę, a nawet wzbudzić podziw polskiej inteligencji, która uznawała jego znaczącą rolę w życiu intelektualnym Warszawy w okresie międzywojennym. Wielostronność i różnorodność jego osobowości uczyniły z niego zwolennika zarówno kultury rosyjskiej, jak i polskiej32.

26 B. Białokozowicz, Józef Czapski i triumwirat literacki (Dymitr Mereżkowski, Zinaida Gippius i Dymitr Fitosofow), seria „Kresy i Pogranicza”, Olsztyn 1995, s. 148-149; zob. też P. Mitzner, Fitosofow i Czapskije, „Nowaja Polsza” 2010, nr 2, s. 32-37.

27 D. Fiłosofow, Mickiewicz w Turcji, „Mołwa” 1932, nr 113; idem, Profiessor Julij Kleiner i „Doroga w Rossiju”, „Mołwa” 1933, nr 11-13, 17-20; idem, Mickiewicz w Odessie, „Przegląd Współczesny” 1934, nr 142; idem, Mickiewicz i Branicki, „Wiadomości Literackie” 1934, nr 7.

28 D. Fiłosofow, Palomnik, „Mołwa” 1933, nr 137 (360).

29 D. Fiłosofow, Detoksykacja, „Mołwa” 1932, nr 17.

30 Redagował lub współredagował różne pisma emigracyjne: „Za swobodu!” (1920-1932), „Mołwa” (1932-1934), „Miecz” (1934-1939).

31 I. Obłąkowska-Galanciak, Dymitr Fitosofow i idea wzajemności polsko-rosyjskich okresu międzywojennego, „Acta Polono-Ruthenica” 2000, t. 5, s. 168.

32 J. S. Durrant, „Uż takowa nasza sud'ba...” Nowoje iz warszawskogo archiwa D.W. Fitosofowa, „Nasze nasledije" 2002, nr 63-64, s. 64-90. 
Z drugiej strony należy przyznać, że niechęć, często wzajemna, którą z różnych powodów żywili do siebie przedstawiciele obu narodów, z reguły była po prostu wynikiem braku wiedzy, nieznajomości języka, innej kultury. Na przykład, odpowiadając na pytania ankiety „Wiadomości Literackich” o wpływach literackich, Józef Wittlin wyznaje, że nigdy nie rozumiał i przez to nie kochał Rosjan. „Może dlatego, że nie znam ich języka... Nie rozumiem Rosjan, ani świata, w którym powstają ich dzieła"33.

O różnych światach wspominał też później Erenburg, weryfikując swe dawne wrażenia:

\W I928 roku Polacy i my żyliśmy w różnych światach. Nawet Tuwim, nawet Broniewski wielu rzeczy wówczas nie rozumieli, a i ja także często wyciągałem pochopne wnioski. Działały jeszcze liczne tradycyjne uprzedzenia, okazały się bardzo żywotne ${ }^{34}$.

W trakcie swych późniejszych wizyt pisarz pogłębiał swoją wiedzę i zmieniał optykę, analizował wcześniejsze uprzedzenia, wywodzące się jeszcze z czasów dzieciństwa:

\Przez długi czas Rosjan i Polaków dzielił głęboki rów - pamięć o najazdach, o przelanej krwi. Nauczyciel historii mówił nam, że każdy Polak jest chełpliwy jak szlachcic, że Polskę zgubiło to, iż każdy „pan” w sejmie wołał „veto” i nie dopuszczał do uchwalenia jakiejkolwiek ustawy. Jeden z mistrzów mej młodości, Dostojewski, w swoich powieściach ukazał Polaków w karykaturze. Nie znałem Polski i gdzieś na dnie serca zachowałem do niej uprzedzenie ${ }^{35}$.

Ale zarówno ten pierwszy pobyt w Polsce, jak i następne, a szczególnie opinie ludzi, których Erenburg podziwiał, przyczyniły się do stopniowej zmiany jego poglądów:

\Pamiętam, że w zdumienie wprawił mnie zapał, z jakim Tuwim mówił przy pierwszym naszym spotkaniu o polskim charakterze narodowym. Potem usłyszałem od Babla: „To poetycki naród”. [...] Zacząłem się zastanawiać i dopiero w 1928 roku spędziwszy pewien czas w Polsce coś niecoś zrozumiałem ${ }^{36}$.

33 J. Wittlin, Co zawdzięczaja pisarze polscy literaturom obcym, „Wiadomości Literackie” 1927, nr 48.

34 I. Erenburg, Z pamiętników, s. 46.

35 Ibidem, s. 43.

36 Ibidem. 
Pierwsza wizyta Erenburga w Polsce wywołała ożywioną reakcję: pisały o niej „Wiadomości Literackie”(nr 5I), „Epoka” (nr 232), „Nasz Przegląd”(nr 33I), „Chwila” (nr 312), „Słowo” (nr 227) - i oczywiście rosyjska prasa emigracyjna, której negatywny ton łatwo było przewidzieć ${ }^{37}$. Na przykład redagowana przez Fiłosofowa gazeta „Za swobodu!”, pisząc o przyjęciu w PEN Clubie (6 grudnia), zapowiadała, że główną atrakcją będą przemówienia towarzysza Bogomołowa (przedstawiciel ZSRR w Polsce) Mickiewicz i Stalin oraz Erenburga Goethe i ja oraz Ja i Dante $3^{38}$. W publikacjach na łamach „Za swobodu!” urażony Erenburg dostrzega gorliwą obronę polskiej „ojczyzny” przed Rosjanami, a nawet antysemityzm:

\section{\Pragnienie, aby zadowolić polskich patronów, zmusza wczorajszych li- berałów, bywalców Stowarzyszenia Religijno-Filozoficznego do uczenia się arii pogromowych. Oto artykuł o literaturze: „Erenburg, Pasternak, Mandelsztam zakazują Arcybaszewom i Kuprinom, aby nazywali się rosyjskimi pisarzami”. Gazetę redaguje nie anonimowy pogromca, ale pan Fiłosofow. Najwyraźniej w Polsce można się wiele nauczyć! ${ }^{39}$}

Jednym z tych „polskich nauczycieli” mógłby być Adolf Nowaczyński, który w „Gazecie Porannej Warszawskiej” (nr 333), organie Narodowej Demokracji, pisze złośliwie o „epoce Erenburgów”, wyraźnie żywiąc wobec pisarza niechęć. Sam zainteresowany odpowiada następująco:

\section{\Najbardziej znany z polskich publicystów Nowaczyński zaznaczył moje przybycie artykułem bojowym. On oczywiście łajał mnie, bo jestem I) Rosjaninem, 2) radzieckim, 3) Żydem. Ale jednak interesowało go coś zupełnie innego. Artykuł ten nazywał się „Erenburg w mieście Ehrenberga" i w nim, używając podobieństwa nazwisk, rozliczał się on z innym warszawskim publicystą - Ehrenbergiem ${ }^{40}$.}

37 Tak pisano w gazecie rosyjskiej emigracji: „Jest rzeczą oczywistą, że nie mamy nic przeciwko przybyciu tego pisarza do Warszawy. Co więcej, nie mamy prawa ingerować w pracę Polaków na polu «kulturowego» zbliżenia z bolszewikami. Jesteśmy nawet gotowi uwierzyć, że Ilja Erenburg należy do grona «przyjaciół-Moskali», a mimo to pozwolimy sobie wyrazić jedno małe «ale». Zdziwienie budzi fakt, że «utalentowany polski poeta Julian Tuwim», który bardzo dobrze zna literaturę rosyjską, docenia ją, rozumie, czym jest rosyjski język literacki i czym jest prawdziwa literatura, tym niemniej obcuje z Erenburgiem, typowym «międzynarodowym» pisarzem z «dziennikarzy», bez języka, bez poważnego podejścia do słowa” (D. F[iłosofow], On prijechat, „Za swobodu!” 1927, nr 279).

38 B. Frezinski, Ilja Erenburg i Polsza (1923-1960), s. 285.

39 I. Erenburg, W Polsze, s. 130-131. Wspomina później, że kiedy był w Polsce w 1927 r., antysemici polowali na Tuwima: „pokazał mi gazetę, gdzie pisano, że jego poezja «cuchnie czosnkiem»” (I. Erenburg, Ludi, gody, żyzn', s. 402).

40 Idem, W Polsze, s. 116-117. 
Charakterystyczne jest zresztą to, że - jak zaznacza w swym dzienniku (I2 lutego I963) Korniej Czukowski - ciemna masa w ZSRR nienawidzi Erenburga za to, iż jest Żydem, intelektualistą, człowiekiem Zachodu ${ }^{41}$. Warto pamiętać - Erenburg przyjechał do Warszawy z Paryża, stąd wzięło się jego spostrzeżenie:

》 mówią, że jeśli przyjechać do Polski z Moskwy, to będzie wywierała wrażenie Europy, choćby drugiej klasy, ja przyjechałem z Paryża, więc na pytanie „Jak tu jest?” szczerze odpowiedziałem: „Rosja”. Dotyczy to również drobnostek życia codziennego i struktury duchowej, wyglądu miast i ludzi ${ }^{42}$.

Pisarz spotykał się z Julianem Tuwimem, którego poznał jeszcze w Berlinie w I922 roku (poświęcony mu rozdział, jak przekonuje badacz jego twórczości, jest najbardziej serdeczny ${ }^{43}$ ), z Juliuszem Kadenem-Bandrowskim, Józefem Wittlinem, Władysławem Broniewskim, Tadeuszem Peiperem, Jarosławem Iwaszkiewiczem ${ }^{44}$. O Tuwimie pisał:

\Najbardziej utalentowanym poetą jest Tuwim. Jest to przede wszystkim poeta: żyje wierszami. Całymi wieczorami potrafi czytać wiersze Rimbauda, Puszkina, Mickiewicza czy Pasternaka, ciesząc się jak dziecko z każdego poetyckiego odkrycia. Szybko promienieje i szybko gaśnie. Potem jest ponury, roztargniony... Tylko rytm, słowo, dźwięk moga go rozpalić. Nie jest to kwestia przekonania, sposobu myślenia, nawet wiary, ale struktury duchowej. Myśli dziecinnie i nie można z nim dyskutować. Myśli skojarzeniami, argumentuje asonansami. Jest z tej samej rasy ludzkiej co Toller i Pasternak ${ }^{45}$.

Ponieważ Erenburg zachował przyjazne relacje z Tuwimem przez całe życie, przyznawał później:

》Mam bliskich przyjaciół wśród obcokrajowców; rozmawiając z nimi, nagle czuję - tu jest granica... Zbyt różnie żyliśmy i żyjemy. Nigdy

41 K. Czukowski, Dniewnik. 1930-1969, sost., podgot., kommient. E. C. Czukowskiej, Moskwa 1994, s. 333; zob. S. Nechamkin, Towariszcz Erenburgsnowa uproszczajet..., „Izwiestija” 2006, nr 23.

42 I. Erenburg, $W$ Polsze, s. 105.

43 B. Frezinski, Ilja Erenburgi Polsza (1923-1960), s. 281.

44 Ibidem, s. 281-303.

45 I. Erenburg, W Polsze, s. 112-113. 
nie doświadczyłem czegoś takiego z Tuwimem, nie było między nami nie tylko „żelaznej kurtyny”, ale nawet lekkiej firanki ${ }^{46}$.

Z pamiętników Erenburga widać, jak głęboko był związany z Tuwimem, jak silnie poeta wpłynął na jego odbiór Polski („Polska nie zawsze była łagodna dla Tuwima, ale zawsze kochał Polskę. Charakter polskiego patriotyzmu wiąże się z tragiczną historią trzech rozbiorów. Nigdy o tym nie zapomniałem, słuchając wyznania Tuwima”47); niezrozumiałe dla siebie uwielbienie Łodzi („Z pasją uwielbiał swoją rodzinną Łódź, miasto najmniej stworzone do podziwiania") tłumaczył ogólnymi właściwościami miłości („na tym polega moc miłości, że dużo przeistacza” ${ }^{8}$ ). Wydaje się, że Tuwim stał się dla Erenburga czymś w rodzaju uosobienia Polski; autor Niezwyktych przygód Julia Jurenity... przyznawał jednak, że chyba nie jest w stanie ogarnąć zdumiewającej osobowości swego przyjaciela („Prawdopodobnie Tuwim był znacznie bardziej skomplikowany, niż wydawał się nie tylko dogmatykom z różnych klasztorów, ale także swoim przyjaciołom"49).

Warto zaznaczyć, że prawie jednocześnie Polskę odwiedził Włodzimierz Majakowski, który - w odróżnieniu od przybywającego z Francji Erenburga - przyjechał z Rosji sowieckiej (co zresztą z dumą podkreślał: „Ja - pierwszy poeta, który przyjechał z czerwonej Moskwy"50) na zaproszenie stowarzyszenia pisarzy lewicowych „Blok” oraz PEN Clubu, spędził w Warszawie ro dni i napisał o tym pobycie dwa krótkie szkice - Wyglad Warszawy oraz Ponad Warszawa $q^{5 \mathrm{I}}$, czyli, jak już same tytuły wskazują, spisał wrażenia powierzchowne i ulotne ${ }^{52}$, a poza tym mocno zabarwione ideologią, deklarowanymi preferencjami lewicującej, rewolucyjnej sztuki („są to jedyne jednostki, które powstają do ostatniej walki proletariatu”53). Wśród „najbliższych nam i mnie” wylicza Wandurskiego i Broniewskiego,

46 Idem, Ludi, gody, żyzn', s. 402.

47 Ibidem, s. 400.

48 Ibidem.

49 Ibidem.

50 W. Majakowski, Powierch Warszawy, w: idem, Potnoje sobranije soczinienij w trinadcati tomach, Moskwa 1958 , t. 8, s. 350.

51 Ibidem, Narużnost' Warszawy, s. 344-346; Powierch Warszawy, s. 347-357. Napisał też wiersz Polska (1927), ilustrujący militaryzację kraju, którą rzekomo obserwował. Zob. porównanie polskich wrażeń Majakowskiego i Erenburga w: L. F. Kacys, Wtadimir Majakowski. Poet w intiellektualnom kontiekstie epochi, Moskwa 2000, s. 341-353.

52 Zdawał sobie z tego sprawę i przyznawał: „Jestem przekonany, że poważny czytelnik zna Polskę lepiej i głębiej niż ja. Uważałem jednak za pożyteczne spisanie mojego powierzchownego wrażenia, ponieważ mimo bliskości Polski nasi podróżujący rzadko się tam zatrzymują i chyba rzadko jest to możliwe" (W. Majakowski, Powierch Warszawy, s. 357).

53 Ibidem, s. 350. 
„Dźwignię”, spotyka się z tłumaczami swych dzieł - Tuwimem (Obtok w spodniach) oraz Słonimskim (Lewq marsz). Ten ostatni dodał także do tłumaczenia tego wiersza swoją poetycką polemikę z jego ideologią - Kontrmarsz (tu zamiast „lewą, lewą, lewą” było „w górę, w górę, w górę”). Kiedy Majakowski podziękował mu za przekład Lewq marsz, Słonimski zapytał, czy za odpowiedź też - „Odpowiadam: «za „w górę" niech Pana chwalą w Polsce»” 54 . W odróżnieniu od reakcji prasy na wizytę Erenburga, Majakowski „ze względu na bezstronność” musiał odnotować skrajnie poprawny, ostrożny ton polskiej prasy: „Wściekała się tylko emigracyjna «Za wolność», trąbiąc o przyjeździe"55.

Istotna wydaje się zasadnicza różnica pomiędzy percepcją Polski i Polaków uwarunkowaną ideologią państwową oraz stereotypami w tekstach pisarzy radzieckich $\mathrm{z}$ lat dwudziestych i trzydziestych, preferujących podejście klasowe ${ }^{56}$, często wydających pochopne opinie - oraz radykalnie innym spojrzeniem Fiłosofowa i ludzi z bliskiego mu kręgu. Dopiero po dwunastu latach pobytu w Polsce Fiłosofow wystąpił z artykułem pod wiele mówiącym tytułem Detoksykacja, w którym z wielkim współczuciem pisał o

\ długotrwałym zatruciu, któremu nie $\mathrm{z}$ własnej woli podlegał przez półtora wieku naród polski i jego dusza.

O zatruciu tym my, Rosjanie, wiedzieliśmy wyłącznie teoretycznie, a i to bardzo niewiele, dlatego że żyliśmy daleko od Polski, zajęci swoimi problemami, i co najważniejsze, prawie nikt $\mathrm{z}$ nas nie władał językiem polskim. Jeśli chodzi o mnie osobiście, to dopiero gdy stałem się emigrantem, przeżyłem tu około dwunastu lat i opanowałem język polski na tyle, by czytać po polsku, pojąłem nie rozumem, lecz odczułem na skórze, jak skażona była polska dusza, ile trucizn nazbierało się w niej przez półtora wieku niewoli ${ }^{57}$.

Dla Fiłosofowa, o czym pisze w swym liście z 4 maja 1928 roku do Mariana Zdziechowskiego, rektora Uniwersytetu w Wilnie, istotne jest przeciwstawienie nie systemów politycznych czy, jak u Majakowskiego, sztuki „rewolucyjnej” i „zacofanej, tradycyjnej”, lecz arystokracji ducha i tłumu: „Im dłużej żyję, tym bardziej jestem przekonany, że we wszystkich okolicznościach w historii istniała «republika

54 Ibidem, s. 350.

55 Ibidem.

56 Zob. więcej na ten temat w: W. Choriew, Polsza i poliaki gtazami russkich litieratorow, Moskwa 2005, s. 121-143.

57 D. Fiłosofow, Detoksykacyja, „Mołwa” 1932, nr 17, przedruk: idem, Pisma wybrane, t. 2: Rosjanin w Polsce (1920-1936), ttum. R. Szczęsny, s. 206. 
arystokratów», której członkowie mogli się nawzajem rozumieć, ale której tłum nigdy nie rozumiał" ${ }^{8}$. Oczywiście obaj korespondenci należeli do tej „republiki arystokratów", o czym też świadczy treść i ton ich pełnych zaufania epistolarnych kontaktów. Fiłosofow wysyła później do Zdziechowskiego list (z 7 stycznia I93I roku), w którym pewność, co do podobieństwa ich poglądów i postaw połączona jest $\mathrm{z}$ diagnozą współczesnej im epoki oraz z proroczym pesymizmem $\mathrm{w}$ stosunku do nadchodzących czasów:

》 Głównym zagrożeniem są bolszewicy, a wcale nie dlatego, że ich śmierdzący duch rozciąga się na całą Europę. Humanizm i kultura - jak ich z Panem rozumiemy - zniknęły na dłuższy czas. Obecność bolszewików w Moskwie nauczyła antybolszewików działać według ich metod. Wojna plus komunizm zabiły dawne umiejętności humanitarne na kilka pokoleń w przyszłości ${ }^{59}$.

Wydaje się, że było jeszcze coś, co łączyło dwóch szlachetnych rozmówców najlepiej oddaje to angielskie określenie wishful thinking. Fiłosofow wierzył w antybolszewicką rewolucję, której nadejście usiłował przybliżyć, i pierwotną czystość ludu rosyjskiego, co w rezultacie miałoby doprowadzić do powstania pożądanej, wymarzonej „trzeciej Rosji”. Z kolei zmagania polskiego konserwatysty Zdziechowskiego z Rosją

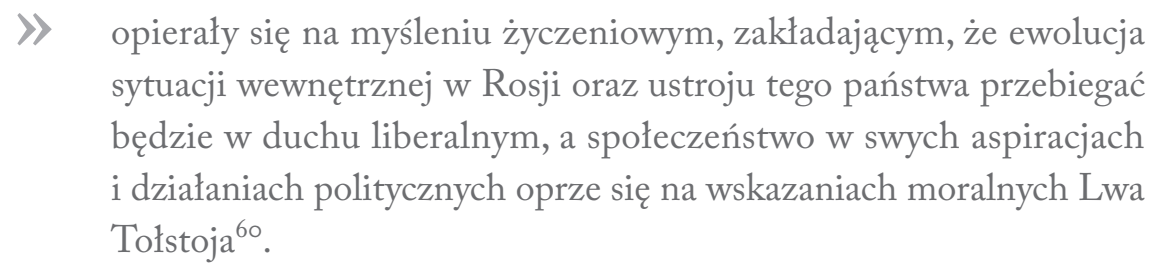

Obaj też wierzyli w siłę kultury, doceniając wartości dziedzictwa duchowego tak polskiego, jak rosyjskiego. Zdziechowski uważał, że w czerwonym sztandarze tkwi symbol końca tej Rosji, która wnosiła swoją obfitą daninę do skarbca ogólnoludzkiej kultury $^{6 \mathrm{I}}$. Wszystko zatem, co miała Rosja najwybitniejszego, znalazło się poza jej

58 Dział Rękopisów Biblioteki Uniwersytetu Wileńskiego, F 33 - 302.

59 Zob. P. Lawryniec, Gumanizm i kultura w naszem s wami ponimanii. Pis'ma Dmitrija Fitosofowa Marianu Zdziechowskomu, „Nowaja Polsza” 2008, nr 10, s. 35-41.

60 Z. Opacki, Mariana Zdziechowskiego zmagania z Rosja, w: Polacy a Rosjanie, red. nauk. T. Epsztein, Warszawa 2000, s. 188.

61 Otkrytoje pis'mo profiessora Mariana Zdziechowskogo Dmitriju Fitosofowu, „Za swobodu!” 1928, nr 262. 
granicami, i właśnie z tą częścią narodu rosyjskiego utrzymywał kontakty, a nawet zawierał przyjánie ${ }^{62}$.

Fiłosofow porównywał dawną polską i dzisiejszą rosyjską sytuację na emigracji, stan panujących tam nastrojów:

》Nam, Rosjanom, trudno jest oderwać się od myśli, że Mickiewicz walczył przeciwko naszej ojczyźnie. Ale proszę, żebyście zrezygnowali z tego uprzedzenia, mając w pamięci szczegóły naszej wojny domowej. Zrozumiecie wówczas, że to, co działo się w I855 roku w Turcji, wśród Polaków, właściwie pod wieloma względami przypomina naszą niedawną przeszłość, nasze ówczesne ruchy ${ }^{63}$.

Jak widać, publicysta „Mołwy” porównywał bohaterski czyn Mickiewicza, wybierającego się w swą tragiczną podróż do Turcji, z zachowaniem współczesnych pisarzy rosyjskich, stawiając pytanie retoryczne:

\Czy można sobie wyobrazić, żeby Bunin, Mereżkowski czy Bierdiajew po dotarciu do cichej, ale też bardzo nobliwej przystani, porzucili wszystko i opuścili Paryż, żeby jechać do jakiegoś Chabarowska, by tam formować oddziały rosyjskie, godzić demokratów-aktywistów z monarchistami i na dodatek - tworzyć specjalny Legion Żydowski? ${ }^{64}$

Wydaje się istotne, że zarówno Fiłosofow, jak i Erenburg, którzy od lat mieszkali poza Rosją, w swoich odniesieniach do niej mają do czynienia raczej z wyimaginowanym symbolem, nieistniejącym w rzeczywistości: Fiłosofow w swych marzeniach konstruował coś podobnego do Rosji Puszkina i Tołstoja, Erenburg (tak samo jak i Majakowski, który zresztą zginął za wcześnie, żeby uświadomić sobie klęskę swego iluzorycznego świata) za punkt odniesienia miał pożądaną republikę szczęścia i sprawiedliwości.

\section{BibLIOGRAFIA:}

Białokozowicz B., Józef Czapski i triumwirat literacki (Dymitr Mereżkowski, Zinaida Gippius i Dymitr Fitosofow), seria: „Kresy i Pogranicza”, Olsztyn 1995;

Choriew W.A., Polsza i poliaki gtazami russkich litieratorow, Moskwa 2005;

62 Z. Opacki, Mariana Zdziechowskiego zmagania z Rosja, s. 90.

63 D. Fiłosofow, Mickiewicz w Turcji, „Mołwa” 1932, nr 113; przedruk: idem Pisma wybrane, t. 2: Rosjanin w Polsce (1920-1936), tłum. E. Skalińska, s. 428.

64 Ibidem, s. 425. 
Durrant J.S., „Uż takowa nasza sud'ba...” Nowoje iz warszawskogo archiwa D.W. Fitosofowa, „Nasze nasledije” 2002, nr 63-64;

Erenburg I., Ludi, gody, żyzn', podgot. I.I. Erenburg, B. J. Frezinski, Moskwa 1990;

Zpamiętników, tłum. W. Komarnicka, „Twórczość” 1964, nr 3;

W Polsze, Berlin 1930; wyd. 2 poszerzone: Moskwa-Leningrad 1931; wyd. 3: Leningrad 1933;

W Polsze, w: idem, Sobranije soczinienij, w 8 t., t. 4, sost., podgot. tieksta I.I. Erenburg i B.J. Frezinskogo, kommient. B.J. Frezinskogo, W.W. Popowa, Moskwa 1991;

Fast P., Aleksander Wat o pisarzach rosyjskich: Boris Pasternak i Ilja Erenburg, „Pamiętnik Literacki” 2010, z. 3;

Fiłosofow D., Detoksykacyja, „Mołwa” 1932, nr 17;

Kriticzieskijestatii izamietki (1899-1916), priedisłowije, sostaw., primieczanija O.A. Korostelewa, Moskwa 2010;

Mickiewicz i Branicki, „Wiadomości Literackie” 1934, nr 7;

Mickiewicz w Odessie, „Przegląd Współczesny” 1934, nr 142;

Mickiewicz w Turcji, „Mołwa” 1932, nr 113;

Palomnik, „Mołwa” 1933, nr 137;

Pisma wybrane, t. 1: Trudna Rosja (1902-1916), oprac. P. Mitzner, Warszawa 2015;

Pisma wybrane, t. 2: Rosjanin w Polsce (1920-1936), wybór i oprac. P. Mitzner, kwerenda S. Kuziur, tłum. H. Dubyk, E. Skalińska, R. Szczęsny, Warszawa 2015;

Profiessor Julij Kleiner i „Doroga w Rossiju”, „Mołwa” 1933, nr 11-13, 17-20;

Zagadki russkoj kultury. Sbornik statiej, sost., primieczanija T. F. Prokopowa, priedisłowije A. N. Nikolukina, Moskwa 2004;

Ilja Erenburg w Polsze (1923-1960), w: Russkije jewriei w Polsze, ried., sost. K. Kikoin, I. Obuchowa-Zielinska, M. Parchomowski, Jerusalem 2014;

Iwaszkiewicz J., Wspomnienie o Erenburgu, „Twórczość” 1967, nr 11;

Kacys L., Wladimir Majakowski. Poet w intiellektualnom kontiekstie epochi, Moskwa 2000;

Lawryniec P., Gumanizm i kultura w naszem s wami ponimanii. Pis'ma Dmitrija Fitosofowa Marianu Zdziechowskomu, „Nowaja Polsza” 2008, nr 10;

List otwarty profesora Zdziechowskiego do D. W. Fitosofowa, „Za swobodu!” 1928, nr 262;

Majakowski W., Narużnost' Warszawy; Powierch Warszawy, Polsza, w: idem, Potnoje sobranije soczinienij w trinadcati tomach, Moskwa 1958, t. 8;

Mitzner P., Fitosofow i Czapskije, „Nowaja Polsza” 2010, nr 2;

Warszawski „Domek w Kolomnie”. Rekonstrukcja, Warszawa 2014;

Warszawski krag Dymitra Fitosofowa, Warszawa 2015;

Nechamkin S., Towariszcz Erenburg snowa uproszczajet..., „Izwiestija” z 9 lutego 2006 r.;

Obłąkowska-Galanciak I., Gorzkie gody... Publicystyka i literacka dziatalność Dymitra Fitosofowa na emigracji, Olsztyn 2001;

Dymitr Fitosofow i idea wzajemności polsko-rosyjskich okresu międzywojennego, „Acta Polono-Ruthenica” 2000, nr 5;

Opacki Z., Mariana Zdziechowskiego zmagania z Rosja, w: Polacy a Rosjanie, red. nauk. T. Epsztein, Warszawa 2000 ;

Popow W., Frezinski B. J., Ilja Erenburg: Chronika żyzni i tworczestwa 1924-1931, Sankt Petersburg 2000, t. 2; 
Rubenstein J., Tangled Loyalties. The Life and Times of Ilya Ehrenburg, Tuscaloosa 1996;

Sarnow B., Wstęp, w: I. Erenburg, Ludi, gody, żyzn', Moskwa 1990;

Słonimski A., Moja podróż do Rosji, „Wiadomości Literackie” 1932, nr 27-35 (wydanie późniejsze: 1997);

Urbańska J., Radziecka powieść rosyjska w Polsce w latach 1918-1932, Wrocław 1966;

Van Poucke P., Erenburgi Polsza, w: For East is East: liber amicorum Wojciech Skalmowski, „Orientalia Lovaniensia Analecta" 2003, nr 126;

Wat A., Mój wiek. Pamiętnik mówiony, rozm. prowadził, przedm. opatrzył Cz. Miłosz, Warszawa 1998;

Wisner H., Książka radziecka i rosyjska w drugiej Rzeczypospolitej, „Kwartalnik Historyczny” 1977, nr 4;

Zarzycka-Bérard E., Burzliwe życie Ilii Erenburga. Rosyjski los, żydowskie szcześscie, thum. A. Kozak, Warszawa 2002.

\section{Czasopisma:}

„Epoka” (z dn. 3 grudnia 1927);

„Mołwa” (roczniki 1932-1934);

„Miecz” (roczniki 1934-1939);

„Za swobodu!” (roczniki 1920-1932).

SŁowa KLUcze: polsko-rosyjskie relacje kulturowe, Ilja Erenburg, Włodzimierz Majakowski, Dmitrij Fiłosofow

\section{ВикТОРИя МочАловА \\ ИАЬЯ ЭРЕНБУРГ И АМИТРИЙ ФИАОСОФОВ: АВА ВЗГАЯАА НА ПОАЬШУ МЕЖВОЕННОГО ПЕРИОАА}

В статье преАставлена попытка сравнительного анализа восприятия Польши русскими поэтами и писатемями, которые ее посетили в межвоенный периоА (ИАья Эренбург, ВАадимир Маяковский), или эмигрировали сюАа (Амитрий Философов). Их взгляды и оценки обусловлены не только различиями жизненного опыта, духовного горизонта, идеологическими установками, но и степенью знакомства с польской действительностью, культурой. Поначалу весьма поверхностные взгляды и оценки ИАьи Эренбурга эволюционировали по мере его ознакомления с польской культурой; восприятие же Польши Амитрием Философовым основывалось на глубоком погружении в польскую Аитературу, историю и современную реальность. Вместе с тем, соотнося польский и российский опыт, каждый из них обращался к воображаемому образу России: Эренбург конструировал идеальный образ страны счастья и справедливости, Философов мечтал о «третьей России», следующей традициям Пушкина и Томстого. 
КАЮчЕВЫЕ САОВА: Польско-рУсские куАьтурНЫе связи, ИАья Эренбург, ВАаАимир Маяковский, Амитрий Фикософов

\section{WikTORia MoczaŁoWA}

\section{Ilya Ehrenburg and Dmitry Filosofov: two outlooks on Poland of THE INTERWAR PERIOD}

The article presents an attempt at a comparative analysis of how Poland was perceived by Russian poets and writers who visited the country in the interwar period (Ilya Ehrenburg, Vladimir Mayakovsky), or emigrated to it (Dmitry Filosofov). Their views and opinions stem not only from the differences of life experience, spiritual horizons, or ideological stance, but also from the degrees of familiarity with Polish reality and culture. The, initially superficial, outlooks and judgments of Ilya Ehrenburg were evolving as he was becoming more acquainted with Polish culture; conversely, Dmitry Filosofov's perceptions of Poland relied on deep immersion into Polish literature, history and contemporary reality. At the same time, correlating Polish and Russian experiences, neither of them was free from wishful thinking: Ehrenburg would build an imaginary portrait of Russia as a country of happiness and justice, and Filosofov dreamt of the 'third Russia' that would follow the tradition of Pushkin and Tolstoy.

KEYwords: Polish-Russian cultural relations, Ilya Ehrenburg, Vladimir Mayakovsky, Dmitry Filosofov 